\title{
The Greek Doctor in Ptolemaic, Roman, and Byzantine Egypt
}

\author{
Ann E. Hanson
}

In the latter half of 1980s Hermann Harrauer canvassed the doctors mentioned in Greek papyri during the some thousand years that these were proving a new and important source for information about individual i $\alpha \tau \rho o$ an and the medical profession more generally, as well as juxtaposing his list of doctors to the lists of other professionals commonly encountered in texts on papyrus. ${ }^{1}$ Harrauer's list

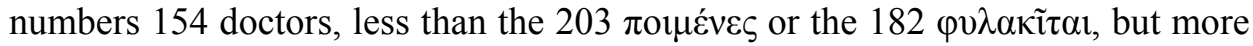
than the 97 workers in the olive oil trade, the 94 fullers, the 73 cooks, and the 50 teachers, which latter group includes those who sign didascalic contracts with students, 13 of whom are to be taught the art of weaving.

In 1909 Karl Sudhoff prepared the earliest census of i $\alpha \tau$ coi in papyri, listing 24 doctors. ${ }^{2}$ Harrauer's counting some eighty years after Sudhoff's reveals a sevenfold increase in the number of individual doctors known to us, an increase that is to be attributed to the vigorous publication of papyri during the long twentieth century. In the post-Harrauer era, the list of doctors appearing in papyri easily exceeds 200, although rules for counting physicians' heads are no longer sufficiently precise as to yield an exact head count. Marie-Hélène Marganne produced the first discrete catalog of papyri with medical content in $1981,{ }^{3}$ and Isabella Andorlini brought a new precision to medical matters in papyri: in addition to collecting and publishing new and newly-corrected medical texts, she was moving toward a more expansive notion of what 'medical material' might entail. ${ }^{4}$

\footnotetext{
${ }^{1}$ Harrauer, Steuerwesen, esp. Sections C-D, pp. 41-174. Prominent among more recent data on doctors from the Ptolemaic period is, for example, Clarysse/Thompson, Counting II, 55, 57, 88, 162 4, 151, 171, 199, 322, 342; and Clarysse/Thompson, $P$. Count 2. Among more recent texts dealing with doctors from the Roman and Byzantine periods, P.Oxy. LXXX, ed. by M. Hirt, D. Leith, and W.B. Henry (2014); and the ever-increasing accumulation of reports from public physicians and other medical personnel from metropoleis, most often from Oxyrhynchus in the Roman period, P.Oxy. LXXX 5254 (AD 89-94), P.Oslo III 95 (96), BGU II 647 (130), P.Oxy. LXXX 5255 (II cent.), LXXX 5256 (190), LVIII 3926 (246), P.Mert. II 89 (300), P.Oxy. LXXX 5257 (312), VI 896 (316), LI 3620 (326), P.Rein. II 92 (393). For P.Oxy. III 476 (ca. 159-61), see Reggiani, Cadaveri; and also the international conference organized by I. Andorlini and N. Reggiani, "Medical Papyri in a Digital World," University of Parma, September 7-8, 2015. Cf. also Hirt Raj, Médecins, passim.

2 Sudhoff, Ärtliches.

${ }^{3}$ Marganne, Inventaire.

${ }^{4}$ Andorlini Marcone, Apporto; for Andolini's bibliography, see Andorlini, Scritti, XI-XVII.
} 
More than anyone, Andorlini sensed the importance of uniting the many facets of what can be learned about medicine in the ancient Mediterranean world from papyri retrieved from the Eastern Mediterranean - and from Egypt in particular during Ptolemaic, Roman, and Byzantine times. Only digitization and continued web presence make such a medical library in all its complexities, such as she envisioned, a reality. ${ }^{5}$ In addition to the traditional work of papyrology, the editing of new texts and the constant amelioration of what is already edited and in the public domain, there are to be medical/historical dimensions that trace the introduction of new medical sects, development of new medical genres, and the profession's ever-changing cast of characters that come and go over time, alongside continuing popularity of the older things and earlier people, but not all: the Hippocratic Aphorisms and the figure of Hippocrates remain of interest. There was their medical language, sometimes formal, and at other times not; the naming of the realia, the instruments, and the ingredients. ${ }^{6}$ The medicinal recipes bring another aspect to investigate, whether a copy of a single prescription on a papyrus scrap or a substantial collection housed in a papyrus roll. ${ }^{7}$ Some recipes were incorporated into the manuscript traditions, from the Compositiones of Scribonius Largus, or Galen's large drug books (De compositione medicamentorum secundum locos in ten books and De compositione medicamentorum per genera in seven books, in addition to smaller collections), or toward the end of Antiquity the compendia by Oribasius, Aetius, and Paulus Aegineta. ${ }^{8}$ Stories and legends

\footnotetext{
Andorlini gathered and published the two volumes of Greek Medical Papyri I and II (Istituto Vitelli, Florence 2001, 2009), with editions of texts prepared by the different hands of her collaborators; those edited by Andorlini's own hand are listed separately in the bibliography prepared by Reggiani and mentioned above (and see also Andorlini, Edizioni, passim). Her project to create a Corpus of Greek Medical Papyri with full commentary, translation, and manifold types of Hilfsmittel began as a print project (see Andorlini, Progetto), but over time evolves together with the relevant internet resources into an online Corpus for ancient medicine: cf. Andorlini/Reggiani, Edizione; Reggiani, Andorlini, esp. pp. 150-7, and Papirologia medica.

${ }^{5}$ Andorlini's project, "Online Humanities Scholarship: A Digital Medical Library Based on Ancient Texts," abbreviated DIGMEDTEXT, has come to include both literary and paraliterary medical texts, with The Michigan Medical Codex, L.C. Youtie ed., being an early entry and 'testcase' for the Digital Corpus of Literary Papyri. See Reggiani, Digital Papyrology I, esp. Appendix 2, pp. 273-275. Also available for inspection is the multifaceted "Corso di Papirologia" website $(<\mathrm{http}: / /$ www.papirologia.unipr.it $>)$, the latest dated posting of which is the "Giornata in ricordo di Isabella Andorlini," dated Thursday, 26 January 2017, some forty days after Isabella's death. This represents a great loss to papyrology and to all who worked with Andorlini, taking pleasure in her vigor, her precision, and her brilliance. On her human and professional profile see now Reggiani, Andorlini.

${ }^{6}$ Some general remarks and case-studies on the medical technical language in the papyri are provided by Maravela, Micro-language.

${ }^{7}$ On the multiple technical aspects of medical prescriptions or recipes on papyrus see Andorlini, Prescriptions, Gergo, Ricette, Tipologia.

${ }^{8}$ On the transmission of medical prescriptions see Andorlini, Tradizione; Reggiani, Prescrizioni and Transmission.
} 
about doctors circulating during ancient times frequently inform more about medical aspirations, such as the pseudepigraphic letters of Hippocrates, ${ }^{9}$ or Apuleius' portrait of the good doctor in the tenth book of his Metamorphoses. In the more mature form toward which this Medical Library is still growing it continues to thrive on its own burgeoning inclusiveness, and although pleased to find a place for all things ancient and medical, the project is designed to be buoyed forever by the fact that those who labor within it continue to find more that needs to be done, to be absorbed, to be gathered in.

When Harrauer assesses his own findings about ancient doctors in 1987 (pp. 96-100), one of the first topics he addresses are the public physicians ( $\delta \eta \mu$ ó

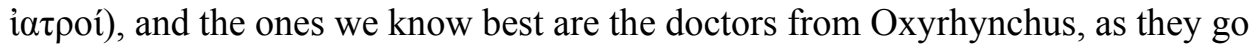
about the Oxyrhynchite nome inspecting instances of injuries and deaths, often dispatched by the strategos together with an assistant (hyperetes), as the result of a petition submitted to him requesting that such an inspection take place. ${ }^{10}$ By this point in time nearly thirty years later, the evidence about public doctors has accumulated apace to the point that not only do public doctors issue reports at Oxyrhynchus, but they are known to be active in capital cities of other nomes Herakelopolite, Arsinoite, Hermopolite, Apollonopolite, Antaiopolite, and Antinopolite, once the Hadrianic foundation of Antinopolis comes into being. ${ }^{11}$

In addition to public doctors in the metropoleis writing up their reports, a doctor with a surgery is recorded in the large Arsinoite village of Karanis, C. Menicius Valerianus, himself probably a retired veteran doctoring to resident veterans who are spending their latter years in Karanis after their days of active service are over. Menicius' sworn declaration claims he not only inspects and reports about the wound Mystharion received, but also that he provides treatment as well (BGU II 647 , AD 130). ${ }^{12}$ The earliest doctors' reports that have been published come from the end of the first century AD and these continue to the very end of the fourth

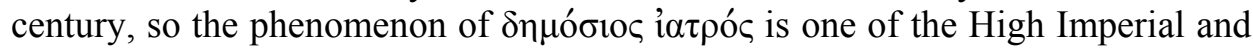
Byzantine periods. Medical services in the capital cities of the nomes, the metropoleis, seem to have been readily available and even sophisticated, catering mostly to the Greek-speaking inhabitants. The countryside was apparently less well provided for from the Ptolemaic period onward, although some farming villages, such as the Arsinoite Tebtunis, are known for vigorous medical activity with collections of texts in both Greek and Egyptian. ${ }^{13}$

\footnotetext{
${ }^{9}$ Cf. recently Smith, Writings.

${ }^{10}$ On this topic see now the observations by Reggiani, Rapporti and Ispezioni.

${ }^{11}$ According to Clarysse/Thompson, Counting II, 162-4, the Greek doctors appearing in salt-tax registers are likely to be residents of the metropolis of the Arsinoite nome, thus marking them an urban phenomenon already in Ptolemaic times. Greek doctors are sometimes located in villages, as are Egyptian ones: cf. Hanson, Tebtunis.

${ }^{12}$ Two mummifiers are also known to have produceed a report on a corpse in the Oxyrhynchite nome: cf. Reggiani, Cadaveri.

${ }^{13}$ Cf. Hanson, Tebtunis.
} 
Testimony about the relative lack of medical services available in the harsh and rocky conditions of the Eastern Desert becomes apparent mostly subsequent to Harrauer's list, with the recent excavations that uncover the short notes written on potsherds during the second century $\mathrm{AD}$, either adjacent to the stone quarries or the Roman-period fortlets lining the route between Koptos and Berenike. In the reign of Trajan, according to a survey of the personnel active at Mons Claudianus, there is a single doctor in residence, together with six druggists (O.Claud. IV 708 i 4: i $\alpha \tau \rho \grave{c} \varsigma \alpha, 12: \varphi \alpha \rho \mu \alpha \xi(\alpha \operatorname{\alpha iol)~} \varsigma)$. Nonetheless, medicaments may be what is particularly hard to come by in the desert, and self-help is often the more successful recourse. Menelaos complains to his friend that his rose oil has been stolen while he was at Mons Claudianus, but, as there was no way to buy more to restore his loss, he begs his friend to send him a small jar (O.Claud. I 171). Julius, apparently stationed at the small fortification of Didymoi, writes to Antonius:

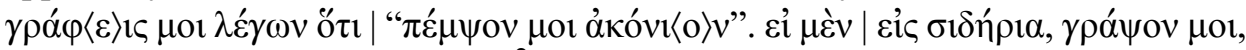

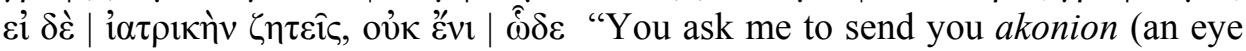
medicament known to the herbalist Dioscourides). If you want iron weapons, certainly write to me, but if you want medicine for your eyes, well, there's nothing of that sort around here" (O.Did. 323,2-6; ca. AD 125-140).

Harrauer also notes that doctors appear to serve more frequently as writers for those of their fellows who do not know letters than do many other professionals. It may be the case that 'i $i \tau \rho o$ s' $\varsigma$ ' is by habit more often attached to the personal name of someone who is a doctor than are the names of other professions, such as teacher, $\delta ı \delta$ á $\sigma \alpha \lambda$ os. The Ptolemaic salt-tax registers published in P.Count show professions attached to the names of both teachers and doctors because both groups eventually receive exemptions from that tax. ${ }^{14}$ Some doctors and teachers enjoy tax exemptions in the Roman Empire, yet the number of those with the highest honorary positions is strictly limited. ${ }^{15}$

The instances of doctors writing for someone who states that he or she does not know letters are interesting in their own right. The documents furnish additional testimony not only to the literacy characteristic of doctors who practice medicine among city-dwelling populations, but they also join company with the doctors who witness contracts and write their signatures that attest to their activity as witnesses. ${ }^{16}$

\footnotetext{
${ }^{14}$ Clarysse/Thompson, Counting II, 125-13: teachers of Greek; 162-4: Greek doctors. For exemptions in the Roman period, cf. P. J. Parsons, P.Coll.Youtie 66, Appendix 2, pp. $441-4$ (grammarians and doctors). On the specification of professions as an indication of tax status see the observations in Reggiani, Identifying.

${ }^{15}$ Cf. Reggiani, Rapporti.

${ }^{16}$ For example, P.Mich. XIII 664,40-50 (Aphrodites Kome, Antaiopolite nome, AD 599), in which a skillful professional scribe ( $\tau \alpha \beta \varepsilon \lambda \lambda i \omega v)$, Constantinus, writes the body of the text for Aurelia Judith, while David, son of Andreas (a priest who is a male relative by marriage) writes her signature for her in a slow but legible hand, expressing her agreement to the contract of sale. Three others bear witness to the contract: the doctor Aurelius Theodorus, son of Paulus, but little space has been left to the doctor for writing his testimony; his hand is certainly one of the more legible ones among the
} 
The high level of doctors' literacy ${ }^{17}$ no doubt helps to explain the extensive medical materials, both literary and paraliterary texts, unearthed at Oxyrhynchus, and Antinopolis. It is certainly no accident that the only copy thus far known of the so-called Hippocratic Oath to have survived to our time, written down in a casual hand dated from late-third to early-fourth century AD, was unearthed at Oxyrhynchus (P.Oxy. XXXI 2547, M-P ${ }^{3} 545.3$ ). ${ }^{18}$

The fragment contains a version of Hp. Jusj. 1-4 that diverges widely from the medieval manuscript tradition. This passage of the Oath deals with the transfer of medical knowledge, the doctor's obligations towards his patients, and the refusal of euthanasia and abortion. Can some doctors of ancient Mediterranean be shown to have followed a stricter ethical code than did the general population? Probably not, since the numbers are not great enough to be statistically valid. Nonetheless illiterates show a preference for this set of professionals when looking beyond literate relatives for someone to do their writing for them. That is, illiterates during the some thousand years that Egypt was Greek-speaking, most often turned to members of their own family who could read and write - father, brother, husband son. Yet if these were lacking for any number of reasons - quarrels, incapacity, death - doctors appear in the role of writers for those who cannot write for themselves, apparently looked upon as trusted, literate, and reliable for those illiterates who lacked willing and able kin.

Harrauer follows the editor of P.Sarap. 84a ii 6-9 in thinking that this papyrus letter (\# 67) is pointing to poor penmanship on the part of the doctor Heliodorus, and thus marks him as belonging to a long tradition of medical men writing illegibly.

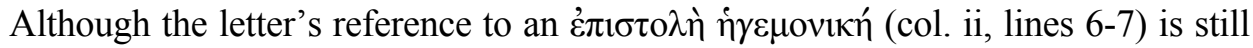

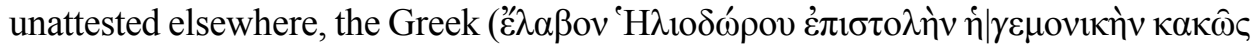

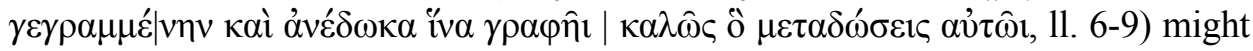
better be translated: "I received from Heliodorus the letter emanating from the prefect's office, not clearly transcribed, and I turned it over so that what you are to say is written out clearly". ${ }^{19}$ And the doctor and his penmanship are exonerated!

witnesses. The second witness, another priest, Senuthes, son of Apollos, humbly styles himself $\dot{\varepsilon} \lambda \alpha \dot{\alpha} \chi(1 \sigma \tau \circ \varsigma)$, "least of priests," and he writes a tolerable hand. In between the second and third witnesses the woman's son, Aurelius Cyriacus, son of Collouthos (Aurelia Judith's husband has died, line 12 and BL VIII 217), signals his agreement and trust in the contract, but does not claim to be a witness, nor is he able to keep the line straight as he writes. The final witness, Synterichus, son of Panymphius, seems the most skillful writer among the witnesses (see P.Mich. XIII, Plate XVII). Both David and Constantinus reappear in P.Hamb. IV 265,12-13.

${ }^{17}$ On this topic see Hanson, Literacy, and Reggiani, Literacies.

${ }^{18}$ Equally from Oxyrhynchus does come a papyrus fragment (P.Oxy. III 437, III cent. AD) containing a medical treatise partly resembling the Hippocratic Oath and therefore to be considered as another version of the Oath itself or a treatise about it (cf. Deichgräber, Standesethik, 111-2, and Wouters, Diels).

${ }^{19}$ See Préaux, Review. 
Harrauer \# 102, P.Vind.Sijp. 1, contains two receipts given by shipmasters to Aurelius Adelphius, collector of charcoal in the Hermopolite nome, AD 338. The second receipt ends with a subscription written by the doctor Aurelius Pagenes

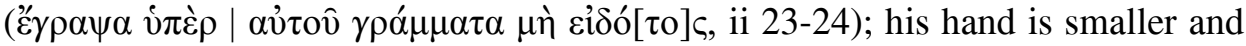
more regular than the first hand and Pagenes also writes the subscription, now mutilated, at the end of the first receipt (i 21-22), in addition to the body of the second receipt. ${ }^{20}$

In Harrauer \# 130, P.Lond. III 1044,34-39 (= Chr.M. 367, Hermopolis, VI cent.), Aurelius Anouthis, son of Iosephios, diakon from Hermoupolis and doctor, when asked, wrote for Aurelia Aphthonia, illiterate, daughter of Taurinos, donor of the

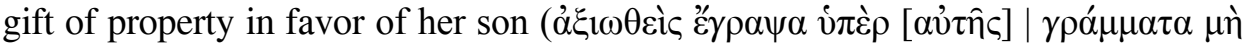
Eỉovíac, 11. 38-39).

In Harrauer \# 141, P.Alex. 34,10-11 (Alexandria?, IV-V cent.), contract for a loan of money, Aurelius Aphonios, son of Pachomsais, doctor, from the same city

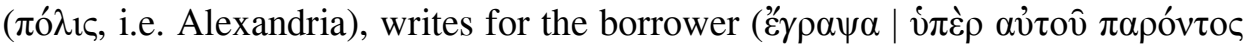

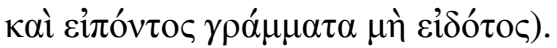

In Harrauer \# 148, P.Apoll. 58,3-4 (Apollonopolis Magna, archive of the pagarch Papas, dated to the $2^{\text {nd }}$ half of the VII cent. $\left.{ }^{21}\right)$, contract of loan with mortgage, Phêy, son of Papnouthis, doctor, when asked, wrote for the borrower as

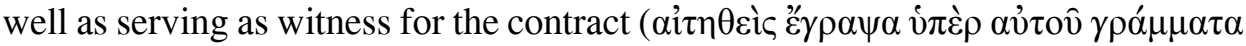

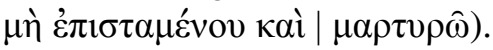

After Harrauer's list, we record a rather opposite case in SB XXII 15245 (Arsinoite nome, VI cent.), the last lines of a contract for the lease of a work-place

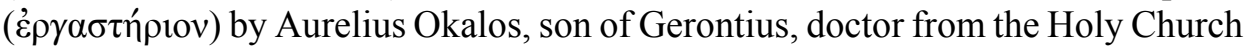
of . . . the Apostles (verso, lines 1-2). Aurelius Neilammon, son of Abraam from

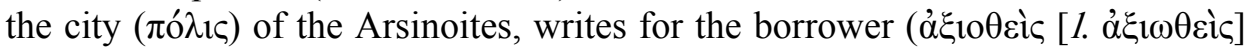

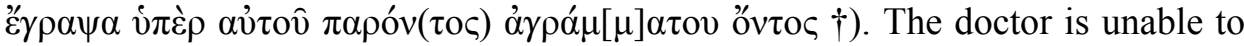
sign the document in Greek, although he is likely to be literate in Egyptian. ${ }^{22}$

If doctors of Roman and Byzantine Egypt were reading the Oath attributed to Hippocrates, surely it would have been these men, or men like them for whom the Oath was a text to be read. David Leith has properly emphasized, not only that "[t]here is no evidence that the Oath was ever sworn beyond the original circumstances of its composition," but that it is also clear that by Late Antiquity the Oath had become a text of ethical importance which beginners ought to read at the outset of their studies. ${ }^{23}$ When Valentin Rose was preparing his edition of the Pseudo-Soranian Quaestiones medicinales, as it appears in the second part of his Anecdota Graeca et Graecolatina, Berlin 1870, he found the little letter

\footnotetext{
${ }^{20}$ For the text, cf. Youtie, Notes.

${ }^{21}$ Cf. BL VIII 10; Gascou/Worp, Problèmes, 83-9.

${ }^{22}$ On the issue of Greek and Egyptian medical literacy see now Mairs, Grammata.

${ }^{23}$ Leith, Oath.
} 
Soranus filio karissimo salutem (pp. 243-7) that precedes the text of the Quaestiones in the manuscript Londinensis Cottonianus Galba E IV useful on several counts. His edition prints the letter as an introductory part of the main text, Quaest.med. (pp. 247-74), for the letter provides, or at least suggests, Soranus as an appropriate name for the author of the more substantial text, the Quaest.med., and it advances the claim that medical students ought to begin their studies with the Oath attributed to Hippocrates, a topic often discussed in medical circles of the Roman and Byzantine periods. The letter serves as an appropriate introductory for the Quaest.med., jumping quickly from "Apollo inventing the art of medicine and Aesculapius expanding it, to conclude with Hippocrates as the one who brought the art of medicine to perfect maturity." Soranus seems particularly able to fit the letter's program in the sense that its bipartite presentation looks first to the person who is to learn the art of medicine and then to the art itself, much as he set up the program for his Gynaikeia (I 1) that looks first at the figure of the midwife, maia, and then at the things with which the midwife is faced.

Two texts from Oxyrhynchus, ${ }^{24}$ both dated to the II century AD by the hand that copied them on the backs of papyri, provide evidence for active discussion of where to begin medical education actually taking place at a considerable distance from the great medical centers of the Mediterranean world, and both seem to be presenting chance paragraphs extracted from more extensive medical treatises, perhaps initial paragraphs or introductions. P.Oxy. LXXIV 4970 parallels the advice of the mid-I AD pharmacist Scribonius Largus (Praef. 5), who says that "Hippocrates, founder of our art of medicine, has handed down the precept that the beginning of medical learning should be from the Oath." PSI XII 1275, on the other hand, endorses the claim of Rufus of Ephesus in his De corporis humani appellationibus, Praef. 6-7, that medical education is best begun with students learning anatomical nomenclature. The Oath may have eventually dominated in the Greek-speaking East, as is suggested by the prominence of the Oath in the Alexandrian curriculum and the frequent positioning of the Oath in first place in Byzantine manuscripts. The letter of Soranus to his son that Rose included as introductory to the text of the Quaestiones medicinales has proved unique and does not appear in the two other copies of the Quaestiones, both of which are the elders of MS Cotton Galba E IV - the Carnotensis 62, dated to the end of the tenth century, and the Lincoloniensis 220, dated to the beginning of the twelfth century. ${ }^{25}$ Hence, it is quite likely that the Soranian letter was a deliberate insert intended principally to enhance the claim that medical education should begin with the Oath, for that question was apparently still being contested. ${ }^{26}$

${ }^{24}$ Much useful material on the two papyri, with different views as to where medical teaching ought to begin, in the introduction and commentary to P.Oxy. LXXIV 4970.

${ }^{25}$ See the splendid edition of the Carnotensis 62 (C) and Lincoloniensis 220 (L) by Fischer, Quaestiones.

${ }^{26}$ See Anastassiou/Irmer, Testimonien, 291 n. 2: "K.-D. Fischer (brieflich) außert Zeifel an der 


\section{Bibliography}

Anastassiou/Irmer, Testimonien $=$ Anargyros Anastassiou $/$ Dieter Irmer, Testimonien zum Corpus Hippocraticum I (Nachleben der hippokratischen Schriften bis zum 3. Jahrhundert n. Chr.), Göttingen 2006.

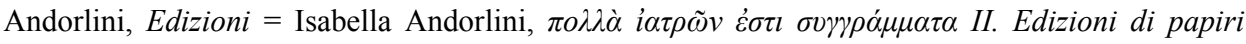
medici greci, N. Reggiani (ed.), Firenze 2018.

Andorlini, Gergo = Isabella Andorlini, Il 'gergo' grafico ed espressivo della ricettazione medica antica, in: A. Marcone (ed.), Medicina e società nel mondo antico (Udine, 4-5 ottobre 2005), Firenze 2006, 142-67 = Andorlini, Scritti, 15-36.

Andorlini, Prescription = Isabella Andorlini, Prescription and Practice in Greek Medical Papyri from Egypt, in: H. Froschauer / C. E. Römer (eds.), Zwischen Magie und Wisseschaft. Ärzte und Heilkunst in den Papyri aus Ägypten, Wien 2007, 23-33 = Andorlini, Scritti, 3-14.

Andorlini, Progetto = Isabella Andorlini, Progetto per il Corpus dei Papiri Greci di Medicina, in: B. Kramer / W. Luppe / H. Maehler / G. Poethke (eds.), Akten des 21. Internationalen Papyrologenkongresses (Berlin, 13-19 8. 1995), Berlin/Boston 1997, 17-24 = Andorlini, Scritti, 337-43.

Andorlini, Ricette $=$ Isabella Andorlini, Ricette mediche nei papiri: note d'interpretazione e analisi

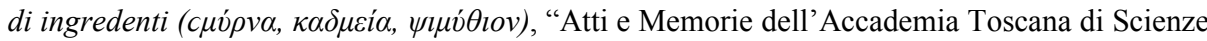
e Lettere 'La Colombaria"” 46, 32 (1981), 33-81 = Andorlini, Edizioni, 63-80 + Scritti, 37-48.

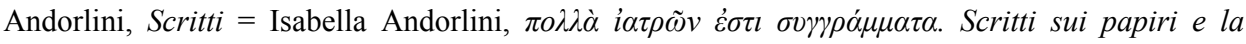
medicina antica, N. Reggiani (ed.), Firenze 2017.

Andorlini, Tipologia = Isabella Andorlini, Tipologia testuale e linguaggio tecnico nelle ricette su papiri: tre casi di ricette conservate dai Papiri della Società Italiana, in: N. Reggiani (ed.), Parlare la medicina: fra lingue e culture, nello spazio e nel tempo. Atti del Convegno internazionale (Parma, 5-7 settembre 2016), Firenze 2018, 113-27.

Andorlini, Tradizione = Isabella Andorlini, I papiri e la tradizione medievale nella ricettazione dei testi medici tardoantichi, in: A. Garzya (ed.), Tradizione e ecdotica dei testi medici tardoantichi e bizantini. Atti del Convegno Internazionale (Anacapri, 29-31 ottobre 1990), Napoli 1992, 13 27 = Andorlini, Scritti, 85-98.

Andorlini Marcone, Apporto = Isabella Andorlini Marcone, L'apporto dei papiri alla conoscenza della scienza medica antica, in: H. Temporini / W. Haase (eds.), ANRW 37.1, Berlin 1993, 458-562.

Andorlini/Reggiani, Edizione = Isabella Andorlini / Nicola Reggiani, Edizione e ricostruzione digitale dei testi papiracei, in: N. Palazzolo (ed.), Diritto romano e scienze antichistiche nell'era digitale. Convegno di studio (Firenze, 12-13 settembre 2011), Torino 2012, 131-46 = Andorlini, Scritti, 363-75.

Clarysse/Thompson, Counting $I I=$ Willy Clarysse / Dorothy J. Thompson, Counting the People in Hellenistic Egypt, vol. II: Historical Studies, Cambridge 2006.

Clarysse/Thompson, P. Count 2 = Willy Clarysse / Dorothy J. Thompson, P. Count 2 Continued: A Ptolemaic Population Register from the Arsinoite Nome, in: K.D. van Heel / F.A.J. Hoogendijk / C.J. Martin (eds.), Hieratic, Demotic and Greek Studies and Text Editions (P.L.Bat. 34), Leiden 2018, 162-89.

Deichgräber, Standesethik $=$ Karl Deichgräber, Die ärztliche Standesethik des hippokratischen Eides, in: H. Flashar (ed.), Antike Medizin, Darmstadt 1971, 94-120.

Zugehörigkeit des Beginns der Quaest. Med. (S. 243-247 Rose) zur genuinen Definitionensammlung Ps.-Sorans." 
Fischer, Quaestiones = Klaus-Dietrich Fischer, Sorani quae feruntur Quaestiones medicinales, Cuenca 2017.

Gascou/Worp, Problèmes = Jean Gascou / Klaas A. Worp, Problèmes de documentation Apollinopolite, ZPE 49 (1982), 83-95.

Hanson, Tebtunis = Ann E. Hanson, Greek Medical Papyri from the Fayum village of Tebtunis: Patient involvement in a local health-care system?, in: P. van der Eijk (ed.), Hippocrates in Context, Leiden 2005, 387-402.

Hanson, Literacy = Ann E. Hanson, Doctors' Literacy and Papyri of Medical Content, in: M. Horstmanshoff (ed.), Hippocrates and Medical Education, Leiden 2010, 187-204.

Harrauer, Steuerwesen = Hermann Harrauer, Corpus Papyrorum Raineri XIII. Griechichische Texte IX. Neue Papyri sum Steuerwesen im 3. Jh. v. Chr., Wien 1987.

Hirt Raj, Médecins = Marguerite Hirt Raj, Médecins et malades de l'Ègypte romaine. Étude socio-légale de la profession médicale et de ses praticiens du Ier au IVe siècle ap. J.-C., Leiden/Boston 2006.

Leith, Oath = David Leith, The Hippocratic Oath in Antiquity and on Papyrus, in: H. Froschauer / C.E. Römer (eds.), Zwischen Magie und Wisseschaft. Ärzte und Heilkunst in den Papyri aus Ägypten, Wien 2007, 35-42.

Mairs, Grammata = Rachel Mairs, Aigyptia Grammata: Linguistic and Medical Training in GraecoRoman Egypt, in: N. Reggiani (ed.), Parlare la medicina: fra lingue e culture, nello spazio e nel tempo. Atti del Convegno internazionale (Parma, 5-7 settembre 2016), Firenze 2018, 3-11.

Maravela, Micro-language = Anastasia Maravela, Medical Micro-language in the Greek Papyri, in: N. Reggiani (ed.), Parlare la medicina: fra lingue e culture, nello spazio e nel tempo. Atti del Convegno internazionale (Parma, 5-7 settembre 2016), Firenze 2018, 12-29.

Marganne, Inventaire = Marie-Hélène Marganne, Inventaire analytique des papyrus grecs de médecine, Génève 1981.

Préaux, Review = Claire Préaux, review of P.Sarap., CE 74 (1962), 398.

Reggiani, Andorlini = Nicola Reggiani, Isabella Andorlini (28 aprile 1955 - 11 novembre 2016), "Aegyptus" 96 (2016), 143-65.

Reggiani, Cadaveri $=$ Nicola Reggiani, Ispezionare cadaveri: mummificatori, medici e anatomisti nell'Egitto greco-romano, MBAH 33 (2015), 75-86.

Reggiani, Digital Papyrology I = Nicola Reggiani, Digital Papyrology I. Methods, Tools, and Trends, Berlin/Boston 2017.

Reggiani, Identifying = Nicola Reggiani, Identifying People in Official Reports: The Administrative Practice in Roman Egypt, in: A. Jördens / U. Yiftach (eds.), Accounts and Bookkeeping in the Ancient World. Question of Structure. Proceedings of the International Conference "Legal Documents in Ancient Societies VIII" (Schwetzingen, September 22-24, 2016), forthcoming.

Reggiani, Ispezioni = Nicola Reggiani, "Ispezioni e perizie ufficiali nell'Egitto romano: il corpus dei rapporti professionali (prosphoneseis), in: A. Marcone (ed.), Lavoro, lavoratori e dinamiche sociali a Roma antica: persistenze e trasformazioni. Atti delle giornate di studio (Roma Tre, 2526 maggio 2017), Roma 2018, 203-19.

Reggiani, Literacies = Nicola Reggiani, Ancient Doctors' Literacies and the Digital Edition of Papyri of Medical Content, "Classics@”, forthcoming.

Reggiani, Papirologia medica = Nicola Reggiani, Isabella Andorlini e la Papirologia medica, in: N. Reggiani / A. Bovo (eds.), Papiri, medicina antica e cultura materiale. Contributi in ricordo di Isabella Andorlini, Parma 2018, 53-62.

Reggiani, Prescrizioni = Nicola Reggiani, Prescrizioni mediche e supporti materiali nell'Antichità, in: N. Reggiani (ed.), Parlare la medicina: fra lingue e culture, nello spazio e nel tempo. Atti del Convegno internazionale (Parma, 5-7 settembre 2016), Firenze 2018, 128-44.

Reggiani, Rapporti = Nicola Reggiani, I papiri greci di medicina come fonti storiche: il caso dei rapporti dei medici pubblici nell'Egitto romano e bizantino, “Aegyptus" 98 (2018), in press. 
Reggiani, Transmission $=$ Nicola Reggiani, Transmission of Recipes and Receptaria in Greek Medical Writings on Papyrus Between Ancient Text Production and Modern Digital Representation, in: R. Berardi / N. Bruno / M. Filosa / L. Fizzarotti (eds.), On the Track of Books: Scribes, Libraries and Textual Transmission, Berlin/Boston 2019, forthcoming.

Smith, Writings = Wesley D. Smith (ed.), Hippocrates, Pseudepigraphic Writings: Letters, Embassy, Speech from the Altar, Decree, Leiden 1990.

Sudhoff, Ärztliches = Karl Sudhoff, Ärztliches aus den griechischen Papyrusurkunden, Leipzig 1909.

Wouters, Diels = Alfons Wouters, Hermann Diels und P.Oxy. 3. 437, "Philologus" 121 (1977), 146-9.

Youtie, Notes $=$ Herbert C. Youtie, Notes on Papyri (III), "Transactons of the American Philological Association" 95 (1964), 300-10 = Id., Scriptiunculae 1, Amsterdam 1973, 400-10. 